\title{
Turn-On and Ratiometric Mercury Sensing in Water with a Red- Emitting Probe
}

\author{
Elizabeth M. Nolan and Stephen J. Lippard ${ }^{\star}$ \\ Department of Chemistry, Massachusetts Institute of Technology, Cambridge, MA 02139
}

\begin{abstract}
The synthesis, photophysical properties, and $\mathrm{Hg}$ (II)-binding of a red-emitting sensor for mercuric ion are presented. MS5, 2-\{11-[(2-\{[bis-(2-ethylsulfanylethyl)-amino]methyl $\}$ phenylamino) methyl]-3-hydroxy-10-oxo-10H-benzo[c]xanthen-7-yl\}-benzoic acid, is based on the seminaphthofluorescein chromophore and employs a thioether-rich metal-binding unit. This sensor affords both turn-on and single-excitation dual-emission ratiometric $\mathrm{Hg}$ (II) detection in aqueous solution. The fluorescence response of MS5 is $\mathrm{Hg}$ (II)-specific and the probe is selective for $\mathrm{Hg}$ (II) over alkali and alkaline earth metals, most divalent first-row transition metal ions, and the Group 12 congeners $\mathrm{Zn}$ (II) and $\mathrm{Cd}$ (II). MS5 binds $\mathrm{Hg}$ (II) reversibly and can be recycled. The $\mathrm{EC}_{50}$ for $1 \mu \mathrm{M}$ MS5 is $910 \mathrm{nM}$ and a lower detection limit of $50 \mathrm{nM}$ is obtained when employing $500 \mathrm{nM}$ probe. Xray crystallographic studies using a salicylaldehyde-based model of MS5 are also presented. 2-[2\{[Bis-(2-ethylsulfanylethyl)amine]methyl $\}$ phenylamine)methyl]phenol coordinates $\mathrm{Hg}$ (II) with two thioether sulfur atoms, two amino nitrogen atoms, and a phenol oxygen atom arranged in a distorted trigonal bipyramidal geometry. Studies of natural water samples spiked with mercuric salts indicate that MS5 can rapidly detect $\mathrm{Hg}$ (II) in such complex solutions and demonstrate its potential utility in the field.
\end{abstract}

\section{Introduction}

A variety of natural and anthropogenic environmental contaminants pose serious problems for human health and ecology. Mercury pollution is a topic of recent concern ${ }^{1-6}$ and has sparked interest in the design of new chemical tools and tactics for its detection. Small molecule sensors that provide selective and immediate response to $\mathrm{Hg}$ (II), observable visually or with simple spectroscopic instrumentation, are particularly valuable. Such probes can ultimately be employed in basic laboratory assays, adapted for measurements in the field through their incorporation into portable fiber optic devices and, as is the case for $\mathrm{Pb}(\mathrm{II})$ detection, fabricated into commercial indictors for household use.

Fluorescence is a powerful optical technique for detecting low concentrations of analytes. A number of fluorescence-based $\mathrm{Hg}$ (II) probes have been reported and include polymers, 7,8 foldamers, ${ }^{9}$ biomolecules, ${ }^{10-12}$ and small molecules. ${ }^{13-32}$ Many fluorescent smallmolecule $\mathrm{Hg}$ (II) sensors presented to date are quenched upon $\mathrm{Hg}$ (II) coordination, rely on an irreversible $\mathrm{Hg}$ (II)-dependent chemical reaction to give fluorescence turn-on, and/or require organic solvent systems, features that may be problematic depending on a given application. Achieving water compatibility is important ${ }^{33}$ and often a challenge in $\mathrm{Hg}$ (II) sensor design. Recently, significant efforts have been made to prepare $\mathrm{Hg}(\mathrm{II})$-sensitive molecules that operate in purely aqueous solution and afford fluorescence enhancement and/or a ratiometric response. 34-44 Many of these detectors utilize fluorescein, ${ }^{35,43}$ rhodamine, ${ }^{37,40,44}$ BODIPY, ${ }^{42}$ or 
naphthalmide 38 reporting groups and exhibit emission in the visible region of the spectrum with $\lambda_{\max } \leq 560 \mathrm{~nm}$. Examples of $\mathrm{Hg}$ (II) sensors with lower energy emission are limited. A phenoxazinone appended with a thioether-rich macrocycle affords maximum emission at ca. $600 \mathrm{~nm}$ in aqueous solution, but $\mathrm{Hg}$ (II) coordination results in fluorescence quenching. ${ }^{45} \mathrm{MS} 4$ (Figure 1) exhibits emission enhancement centered at $624 \mathrm{~nm}$ following $\mathrm{Hg}$ (II) binding, but the change is small ( 2-fold) at neutral $\mathrm{pH}^{35}$. Two probes that respond to $\mathrm{Hg}$ (II) and give near infrared emission in organic solvents have been reported, but their applicability to aqueous milieu was not documented. ${ }^{46,47}$ Designing improved $\mathrm{Hg}$ (II) sensors that emit at relatively long wavelengths, exhibit $\mathrm{Hg}$ (II) sensitivity and selectivity, and have a robust and immediate response to $\mathrm{Hg}$ (II) in water is an important goal. Such probes will be useful in a number of applications, including multi-color analyses requiring sensors that emit at different wavelengths.

In the present article, we address this need and present the synthesis and characterization of Mercury Sensor 5 (MS5, Scheme 1). This sensor is based on a seminaphthofluorescein chromophore, which is water-compatible and affords red-shifted emission relative to fluorescein, rhodamine, and other commonly used reporters. Given the high affinity of $\mathrm{Hg}$ (II) for soft sulfur donors, we chose to incorporate the thioether-rich metal-binding unit previously designed for fluorescein-based MS1 (Figure 1). Because of these design features, MS5 has a number of advantageous features that include (i) turn-on and ratiometric $\mathrm{Hg}$ (II) detection, (ii) rapid and $\mathrm{Hg}$ (II)-specific fluorescence response, (iii) reversibility, and (iv) a detection limit for $\mathrm{Hg}(\mathrm{II})$ in the $\mathrm{nM}$ range. In addition, MS5 exhibits selectivity for $\mathrm{Hg}(\mathrm{II})$ over many competing species, including those found in natural water samples.

\section{Experimental Section}

\section{Reagents}

Anhydrous methanol, chloroform, and 1,2-dichloroethane (DCE) were purchased from Aldrich and used as received. Sodium triacetoxyborohydride and mercury(II) perchlorate hydrate were also obtained from Aldrich. $N^{\prime}, N^{\prime}, N^{\prime \prime}, N^{\prime \prime}$-tetrakis(2-picolyl)ethylenediamine (TPEN) was purchased from Invitrogen. The aniline derivatized ligand $\mathbf{1}^{34}$ and seminaphthofluorescein aldehyde $2^{48}$ were synthesized according to previously published procedures. A portion of 2(10-hydroxy-3-phenylaminomethyl-3H-benzo[c]xanthen-7-yl)benzoic acid, 3, a synthetic precursor to 2 , was prepared as described in the literature 48 and further purified by preparative TLC on silica gel (20:1 $\left.\mathrm{CHCl}_{3} / \mathrm{MeOH}\right)$ for use in spectroscopic studies.

CAUTION-The isolated $\mathrm{Hg}$ (II) complexes described below contain perchlorate ion, which can detonate explosively and without warning. Although we encountered no problems with the isolated compounds, all due precautions should be taken.

\section{Materials and Methods}

Merck 254 silica gel 60 plates ( $0.25 \mathrm{~mm}$ thickness) were used for analytical thin-layer chromatography (TLC) and were viewed with UV light. Whatman silica gel 60 plates (1 mm thickness) were used as the solid phase for preparative TLC. NMR spectra were collected on a Varian 300 or $500 \mathrm{MHz}$ spectrophotometer and the spectra were referenced to internal standards. An Avatar FTIR instrument was used to obtain IR spectra. High-resolution mass spectra were collected by staff at the MIT Department of Chemistry Instrumentation Facility.

\section{2-\{11-[(2-\{[Bis-(2-ethylsulfanylethyl)amino]methyl\}phenylamino)methyl]-3-hydroxy-10- oxo-10H-benzo[c]xanthen-7-yl\}benzoic acid (4, MS5)}

To $9 \mathrm{~mL}$ of a 7:2 $\mathrm{CHCl}_{3} / \mathrm{MeOH}$ mixture were added 1 (71 $\left.\mathrm{mg}, 0.17 \mathrm{mmol}\right)$ and $2(52 \mathrm{mg}, 0.17$ $\mathrm{mmol}$ ), which gave a red-brown solution that was stirred at room temperature. After $24 \mathrm{~h}, 3$ 
$\mathrm{mL}$ of $\mathrm{DCE}$ and $\mathrm{NaB}(\mathrm{OAc})_{3} \mathrm{H}(40 \mathrm{mg}, 0.19 \mathrm{mmol})$ were added and the reaction was stirred for an additional $24 \mathrm{~h}$, during which time it became wine-colored. The solvents were removed under reduced pressure and preparative TLC on silica gel $\left(20: 1 \mathrm{CHCl}_{3} / \mathrm{MeOH}\right)$ yielded pure MS5 as a purple solid (38 mg, 32\%). TLC $\mathrm{R}_{\mathrm{f}}=0.64\left(9: 1 \mathrm{CHCl}_{3} / \mathrm{MeOH}\right) ; \mathrm{mp}>300{ }^{\circ} \mathrm{C}$, dec. ${ }^{1} \mathrm{H}$ NMR $\left(\mathrm{CD}_{3} \mathrm{OD}, 500 \mathrm{MHz}\right) \delta 0.94(6 \mathrm{H}, \mathrm{t}), 2.08(4 \mathrm{H}, \mathrm{m}), 2.24(4 \mathrm{H}, \mathrm{m}), 2.39(2 \mathrm{H}, \mathrm{m})$, $2.47(2 \mathrm{H}, \mathrm{m}), 3.55(2 \mathrm{H}, \mathrm{s}), 4.70(2 \mathrm{H}, \mathrm{q}), 6.64(1 \mathrm{H}, \mathrm{t}), 6.71(1 \mathrm{H}, \mathrm{d}), 6.92(1 \mathrm{H}, \mathrm{d}), 6.98(3 \mathrm{H}, \mathrm{m})$, $7.13(1 \mathrm{H}, \mathrm{d}), 7.20(1 \mathrm{H}, \mathrm{d}), 7.28(2 \mathrm{H}, \mathrm{m}), 7.34(1 \mathrm{H}, \mathrm{m}), 7.61(2 \mathrm{H}, \mathrm{m}), 8.10(1 \mathrm{H}, \mathrm{d}), 8.27(1 \mathrm{H}$, m). FTIR (KBr, cm $\left.{ }^{-1}\right) 3428$ (w, br), 3052 (w), 2957 (w), 2921 (w), 2857 (w), $2800(\mathrm{w}), 1752$ (w), $1641(\mathrm{~m}), 1600(\mathrm{~s}), 1585(\mathrm{~s}), 1563(\mathrm{~m}), 1504(\mathrm{~m}), 1470(\mathrm{~s}), 1443(\mathrm{~s}), 1377(\mathrm{~m}), 1339(\mathrm{~m})$, $1309(\mathrm{~m}), 1251(\mathrm{~m}), 1143(\mathrm{~m}), 1091(\mathrm{~m}), 1070(\mathrm{w}), 1046(\mathrm{w}), 1004(\mathrm{w}), 961(\mathrm{w}), 931(\mathrm{w}), 877$ $(\mathrm{w}), 862(\mathrm{w}), 827(\mathrm{w}), 789(\mathrm{w}), 748(\mathrm{w}), 726(\mathrm{w}), 704(\mathrm{w}), 678(\mathrm{w}), 643(\mathrm{w}), 613(\mathrm{w}), 596(\mathrm{w})$, $526(w), 448$ (w). HRMS (ESI) Calcd [M - H] $]^{-}, 691.2306$; Found, 691.2325.

\section{2-[2-\{[Bis-(2-ethylsulfanylethyl)amine]inethyl\}phenylamine)inethyl]phenol $(5, \mathrm{~L})$}

Salicylaldehyde (376 mg, $3.08 \mathrm{mmol}$ ) and $N$-(2-aminobenzyl)-3,9-dithia-6-azaundecane (1, $914 \mathrm{mg}, 3.07 \mathrm{mmol}$ ) were combined in $40 \mathrm{~mL}$ of EtOAc and stirred for $10 \mathrm{~h}$ at room temperature. The solvent was removed in vacuo to yield an orange-yellow oil. The oil was dissolved in $30 \mathrm{~mL}$ of $\mathrm{DCE}$ and $\mathrm{NaB}(\mathrm{OAc})_{3} \mathrm{H}(700 \mathrm{mg}, 3.33 \mathrm{mmol})$ was added. The reaction was stirred overnight at room temperature, diluted with $40 \mathrm{~mL}$ of dichloromethane, and washed with saturated brine $(3 \times 80 \mathrm{~mL})$ and then water $(1 \times 80 \mathrm{~mL})$. The organic portion was dried over $\mathrm{MgSO}_{4}$ and the solvent was removed to yield an orange oil. Chromatography on $\mathrm{A}_{2} \mathrm{O}_{3}$ with a solvent gradient $(2: 1$ hexanes/EtOAc to $100 \%$ EtOAc) afforded the product as an orange oil that solidified upon cooling at $4{ }^{\circ} \mathrm{C}(812 \mathrm{mg}, 65 \%)$. TLC $\mathrm{R}_{\mathrm{f}}=0.60\left(\mathrm{Al}_{2} \mathrm{O}_{3}, 2: 1\right.$ hexanes/EtOAc). ${ }^{1} \mathrm{H} \mathrm{NMR}\left(\mathrm{CDCl}_{3}, 300 \mathrm{MHz}\right) \delta 1.17(6 \mathrm{H}, \mathrm{t}), 2.37(4 \mathrm{H}, \mathrm{q}), 2.58(4 \mathrm{H}, \mathrm{m}), 2.65$ $(4 \mathrm{H}, \mathrm{m}), 3.70(2 \mathrm{H}, \mathrm{s}), 4.48(2 \mathrm{H}, \mathrm{s}), 6.78-6.91(4 \mathrm{H}, \mathrm{m}), 7.05(1 \mathrm{H}, \mathrm{dd}), 7.16-7.23(3 \mathrm{H}, \mathrm{m}) .{ }^{13} \mathrm{C}$ NMR $\left(\mathrm{CDCl}_{3}, 125 \mathrm{MHz}\right) \delta 14.79,25.88,29.34,47.65,53.02,58.35,113.18,116.33,119.25$, 119.75, 123.64, 124.72, 128.57, 128.90, 130.29, 147.42, 157.16. FTIR ( $\mathrm{NaCl}$ disk, $\left.\mathrm{cm}^{-1}\right) 3217$ (s, br), 3043 (s), 2963 (s), 2924 (s), 2869 (s), 2845 (s), 2817 (s), 2717 (w), 1606 (s), 1588 (s), $1508(\mathrm{~s}), 1490(\mathrm{~s}), 1455(\mathrm{~s}), 1375(\mathrm{~m}), 1314(\mathrm{~m}), 1294(\mathrm{~m}), 1250(\mathrm{~m}), 1149(\mathrm{w}), 1119(\mathrm{~m})$, $1102(\mathrm{~m}), 1050(\mathrm{~m}), 1036(\mathrm{~m}), 983(\mathrm{~m}), 932(\mathrm{~m}), 855(\mathrm{~m}), 839(\mathrm{~m}), 753(\mathrm{~s}), 723(\mathrm{~m}), 658(\mathrm{w})$, 629 (w), 565 (w), 531 (w). HRMS (ESI) Calcd [M + H] , 405.2029; Found, 405.2019.

\section{$[\mathrm{Hg}(\mathrm{L})]\left(\mathrm{ClO}_{4}\right)_{2} \cdot \mathrm{CH}_{3} \mathrm{OH}(6)$}

A portion $(9.7 \mathrm{mg}, 0.024 \mathrm{mmol})$ of $\mathrm{Hg}\left(\mathrm{ClO}_{4}\right)_{2} \cdot \mathrm{H}_{2} \mathrm{O}$ was suspended in $0.5 \mathrm{~mL}$ of $\mathrm{MeOH}$ to which a solution of $5(10 \mathrm{mg}, 0.025 \mathrm{mmol})$ in $0.5 \mathrm{~mL}$ of $\mathrm{MeOH}$ was added dropwise as the solution turned yellow. The solution was sonicated for $5 \mathrm{~min}$ and filtered. Colorless thin needle crystals suitable for X-ray crystallographic analysis formed over the course of $48 \mathrm{~h}$ by vapor diffusion of $\mathrm{Et}_{2} \mathrm{O}$ into the reaction at room temperature. The solvents were decanted and the crystals washed with $\mathrm{Et}_{2} \mathrm{O}(4 \times 3 \mathrm{~mL})$ and dried in vaco $(11.5 \mathrm{mg}, 48 \%)$. FTIR $\left(\mathrm{KBr}, \mathrm{cm}^{-1}\right)$ 3546 (m, br), 3192 (m, br), 3069 (w), 2969 (w), 2932 (w), 2865 (w), 2835 (w), 2700 (w), 2605 (w), 2552 (w), 1609 (m), 1594 (m), 1496 (m), 1460 (s), 1421 (m), 1384 (120m), 1368 (m), 1300 (w), 1258 (m), 1218 (w), 1188 (w), 1102 (s, br), 1084 (s), 1055 (s), 1047 (s), 1004 (m), $932(\mathrm{~m}), 922(\mathrm{~m}), 910(\mathrm{~m}), 884(\mathrm{~m}), 870(\mathrm{~m}), 853(\mathrm{~m}), 832(\mathrm{w}), 801(\mathrm{w}), 770(\mathrm{~s}), 729(\mathrm{w}), 717$ (m), $672(\mathrm{w}), 622(\mathrm{~s}), 575(\mathrm{w}), 543(\mathrm{w}), 521(\mathrm{w}), 494(\mathrm{w}), 484(\mathrm{w}), 468(\mathrm{w})$. HRMS (ESI) Calcd $\left[\mathrm{M}-2\left(\mathrm{ClO}_{4}\right)-\mathrm{H}\right]^{+}, 605.1584$; Found, 605.1578. Anal: Calcd for $\mathrm{C}_{23} \mathrm{H}_{36} \mathrm{Cl}_{2} \mathrm{~N}_{2} \mathrm{O}_{10} \mathrm{~S}_{2} \mathrm{Hg}$ : C, 33.04; H, 4.34; N, 3.35. Found: C, 33.01; H, 4.44; N, 3.30.

\section{$[\mathrm{Hg}(\mathrm{TPEN})]\left(\mathrm{ClO}_{4}\right)_{2}(7)$}

A portion $(7.8 \mathrm{mg}, 0.195 \mathrm{mmol})$ of $\mathrm{Hg}\left(\mathrm{ClO}_{4}\right)_{2} \cdot \mathrm{H}_{2} \mathrm{O}$ in $1 \mathrm{~mL}$ of MeOH was added dropwise to a solution of TPEN $(7.9 \mathrm{mg}, 0.184 \mathrm{mmol})$ in $1 \mathrm{~mL}$ of $\mathrm{MeOH}$. The solution was mixed with a pipette and filtered. Colorless rod-like crystals suitable for X-ray crystallography formed over 
the course of $48 \mathrm{~h}$ from vapor diffusion of $\mathrm{Et}_{2} \mathrm{O}$ into the reaction mixture at room temperature. The solvents were decanted and the crystals were washed with $\mathrm{Et}_{2} \mathrm{O}(4 \times 3 \mathrm{~mL})$ and dried in vacuo (8.6 mg, 57\%). FTIR (KBr, cm $\left.{ }^{-1}\right) 3107$ (w), 3078 (w), 3033 (w), 2963 (w), $2936(\mathrm{w})$, $2911(\mathrm{w}), 2895(\mathrm{w}), 2859(\mathrm{w}), 1600(\mathrm{~m}), 1572(\mathrm{w}), 1486(\mathrm{~m}), 1467(\mathrm{~m}), 1455(\mathrm{~m}), 1441(\mathrm{~m})$, $1386(w), 1374(w), 1335(w), 1318(w), 1300(w), 1294(w), 1263(\mathrm{~m}), 1221(\mathrm{w}), 1159(\mathrm{w})$, 1130 (m), 1095 (vs), 1067 (s), 1051 (s), 1015 (m), 991 (m), 974 (w), 939 (w), 930 (w), 897 $(\mathrm{w}), 866(\mathrm{w}), 841(\mathrm{w}), 802(\mathrm{~m}, \mathrm{br}), 764(\mathrm{~m}), 734(\mathrm{w}), 723(\mathrm{w}), 646(\mathrm{w}), 621(\mathrm{~m}), 584(\mathrm{w})$. HRMS (ESI) Calcd M ${ }^{2+}, 313.1040$; Found, 313.1054. Anal: Calcd for $\mathrm{C}_{26} \mathrm{H}_{28} \mathrm{Cl}_{2} \mathrm{HgN}_{2} \mathrm{O}_{8}$ : $\mathrm{C}$, 37.90; H, 3.42; N, 10.20. Found: C, 37.96; H, 3.23; N, 10.25 .

\section{X-ray Crystallographic Studies}

Single crystals were mounted on the tips of glass fibers coated with Paratone-N oil and cooled to $-100{ }^{\circ} \mathrm{C}$ under a stream of $\mathrm{N}_{2}$ maintained by a KRYO-FLEX low-temperature apparatus. Intensity data were collected on a Bruker APEX CCD diffractometer with graphitemonochromated Mo K $\alpha$ radiation $(\lambda,=0.71073 \AA$ ), controlled by a Pentium-based PC running the SMART software package. ${ }^{49}$ Data collection and reduction protocols are described elsewhere ${ }^{50}$ Empirical absorption corrections were applied by using the SADABS ${ }^{51}$ program and the structures were solved by direct methods using the SAINTPLUS ${ }^{52}$ and SHELXTL $^{53}$ software packages. The structures were checked for higher symmetry by using the PLATON software package. ${ }^{54}$ All non-hydrogen atoms were located and their positions refined with anisotropic thermal parameters by least-squares cycles and Fourier syntheses. Unless otherwise noted, hydrogen atoms were assigned to idealized positions and given thermal parameters equivalent to either 1.5 (methyl hydrogen atoms) or 1.2 (all other hydrogen atoms) times the thermal parameter of the carbon atom to which they were attached. The structure of 6 includes one ordered methanol and two ordered perchlorate anions. The $\mathrm{O} 1$ and $\mathrm{N} 1$ hydrogen atoms of $\mathbf{6}$ were located from an electron density map. The structure of $\mathbf{7}$ includes two ordered perchlorate groups.

\section{Spectroscopic Materials and Methods}

Millipore water $\left(18.2 \mathrm{M} \omega \cdot \mathrm{cm}\right.$ at $\left.25^{\circ} \mathrm{C}\right)$ obtained from a Milli-Q Biocel purifier outfitted with a Quantum VX cartridge was used to prepare all aqueous solutions. PIPES, piperazine- $N, N^{\prime}-$ bis(2-ethanesulfonic acid), CHES, 2-( $N$-cyclohexylamino)ethanesulfonic acid, and CABS, 4cyclohexylamino-1-butanesulfonic acid, buffers were purchased from Sigma and used as received. Puratonic grade $\mathrm{KCl}$ was purchased from Calbiochem. Mercury stock solutions (10 $\mathrm{mM}$ ) were prepared from $99.998 \%$ anhydrous $\mathrm{HgCl}_{2}$ (Aldrich) and water. DMSO stock solutions of 3 ( $2 \mathrm{mM}$, deep red-purple) and MS5 (1 mM, deep purple) were prepared, partitioned into $\sim 40 \mu \mathrm{L}$ aliquots, stored at $-25^{\circ} \mathrm{C}$, and thawed in the dark immediately before use. For measurements conducted in buffered solutions the buffer concentration was $50 \mathrm{mM}$ and, with the exception of the anion variation experiments, $100 \mathrm{mM} \mathrm{KCl}$. The $\mathrm{pH}$ titrations were conducted in the presence of $100 \mathrm{mM} \mathrm{KCl}$. Quantum yields were measured relative to fluorescein in $0.1 \mathrm{~N} \mathrm{NaOH}(\boldsymbol{\Phi}=0.95), 55$ Experimental details for all spectroscopic measurements are available elsewhere. ${ }^{34,43}$ All measurements were repeated a minimum of three times and the resulting averages are reported.

Fluorescence spectra were collected by using a Photon Technology International (Lawrenceville, NJ) Quanta Master 4L-format scanning spectrofluorimeter equipped with an LPS-220B 75-W xenon lamp and power supply, A-1010B lamp housing with integrated igniter, switchable 814 photon-counting/analog PMT detector, and a MD-5020 motor driver. Optical absorption spectra were collected on a Gary IE double-beam scanning spectrophotometer. All samples were contained in $3 \mathrm{~mL}$ quartz cuvettes with 1-cm path lengths (Starna) and maintained at $25^{\circ} \mathrm{C}$ by means of a circulating water bath. 


\section{Water Collection}

Natural water samples from the Charles River (Cambridge, MA), Onondaga Lake (New York state), and the harbor in Newburyport, MA were collected in August 2005 and stored in polypropylene bottles. The water samples were passed through $0.2 \mu \mathrm{m}$ filters to remove particulate and insoluble organic matter prior to use.

\section{Results and Discussion}

\section{Design and Synthesis of MS5}

Several considerations influenced the design of sensor MS5. Our first objective was to employ a fluorophore with relatively low-energy emission relative to fluorescein and other commonly employed chromophores. Metal ion sensors based on seminaphthofluorescein 3 (Figure 1) offer maximum emission at $>600 \mathrm{~nm}$ in aqueous solution, a feature beneficial for applications requiring multicolor detection and for biological use where lower energy excitation is preferred. A second objective was to obtain a sensor with high selectivity for $\mathrm{Hg}$ (II) compared to other metal ions. Ligand 1 was previously employed in the synthesis of MS1 (Figure 1) and confers better selectivity for $\mathrm{Hg}(\mathrm{II})$ than metal-coordinating groups with fewer sulfur donor atoms. Scheme 1 shows the final transformation in the nine-step assembly of MS5.

Combination of aniline $\mathbf{1}$ and aldehyde $\mathbf{2}$ in a mixed $\mathrm{CHCl}_{3} / \mathrm{MeOH}$ solvent followed by imine reduction using $\mathrm{NaB}(\mathrm{OAc})_{3} \mathrm{H}$ afforded sensor $\mathrm{MS} 5$ in $32 \%$ yield as a dark purple powder following purification by preparative TLC on silica gel $\left(20: 1 \mathrm{CHCl}_{3} / \mathrm{MeOH}\right)$.

We also prepared a salicylaldehyde-based analogue of MS5, L, shown in Scheme 1, for use in $\mathrm{X}$-ray crystallographic modeling studies. Ligand $\mathbf{L}$ was obtained in $65 \%$ yield as an off-white solid following Schiff base condensation of salicylaldehyde with aniline 1 and reduction with $\mathrm{NaB}(\mathrm{OAc})_{3} \mathrm{H}$ in DCE.

\section{Spectroscopic Properties and Hg(II) Response of MS5}

Like fluorescein, seminaphthofluorescein (SNAFL) ${ }^{56}$ chromophores exhibit $\mathrm{pH}$-sensitive absorption and emission spectra. The $\mathrm{pH} 7$ to 9 range is particularly important because seminaphthofluorescein platform 3 (Figure 1) undergoes a fluorescence change corresponding to a $K_{\mathrm{a}}$ of $\sim 8$ in aqueous solution containing $100 \mathrm{mM} \mathrm{KCl}$ (Figure S1, Supporting Information). Decreasing the $\mathrm{pH}$ in this range results in fluorescence quenching (Figure S1). This behavior is similar to the fluorescence quenching observed upon protonation of fluorescein, namely, fluorescence quenching $\left(\mathrm{p} K_{\mathrm{a}} \sim 6.4\right)$. The corresponding changes in the optical absorption spectra, depicted in Figure S2, are also analogous to those observed upon fluorescein protonation to form the fluorescein monoanion. ${ }^{57}$ From these comparisons, we conclude that the seminaphthofluorescein monoanion is the predominant species at $\mathrm{pH} 7$ whereas the more emissive dianion is present at higher $\mathrm{pH}$.

We next describe the spectroscopic characteristics and $\mathrm{Hg}(\mathrm{II})$ response of MS5 at $\mathrm{pH} \geq: 7$. Table 1 lists the absorption and emission properties of MS5 in the absence and presence of excess $\mathrm{Hg}(\mathrm{II})$. The changes in optical absorption of free MS5 as a function of $\mathrm{pH}$ are comparable to those of 3 . There are two local maxima $(500,528 \mathrm{~nm})$ of similar intensity at $\mathrm{pH} 7$ and one red-shifted local maximum $(552 \mathrm{~nm})$ of much greater intensity at $\mathrm{pH} 9$ (Figure S3). Similar pH-dependent trends are observed for the MS5:Hg(II) complex (Table 1, Figure S3).

The emission spectrum of free MS5 shows some variations with $\mathrm{pH}$ that differ from those of 3. At $\mathrm{pH} \geq 9$, MS5 exhibits two emission bands centered at ca. 524 and $624 \mathrm{~nm}$ of similar intensity (Figure 2). Decreasing the $\mathrm{pH}$ to $\sim 6$ enhances the $524 \mathrm{~nm}$ band and reduces the 624 $\mathrm{nm}$ band with an isoemissive point at $600 \mathrm{~nm}$. Further acidification results in fluorescence quenching. A $\sim 50 \%$ increase in integrated emission occurs as the $\mathrm{pH}$ is lowered from $\sim 9$ to $\sim 6$, 
which contrasts with the fluorescence decrease observed for $\mathbf{3}$ with increasing acidity. This behavior is similar to that observed for other metal-ion sensors containing aniline-derivatized ligands, including fluorescein-based MS1 ${ }^{34}$ and seminaphthofluorescein-based ZNP1 (Figure 1). 48,58 We attribute the effect to protonation of the aniline unit, which disrupts photoinduced electron transfer quenching. The quantum yields for apo MS5 were determined in the $\mathrm{pH} 7$ to 9 range and are sensitive to $\mathrm{pH}$ changes in this interval. At $\mathrm{pH} 7, \boldsymbol{\Phi}_{\text {free }}$ is 0.018 and its magnitude decreases to ca. 0.01 at $\mathrm{pH} \geq 8$.

The fluorescence of MS5 is enhanced upon $\mathrm{Hg}(\mathrm{II})$ coordination at $\mathrm{pH} \geq 7$. Values for $\boldsymbol{\Phi}_{\mathrm{Hg}}$ are listed in Table 1 and representative emission spectra obtained for MS5 before and after $\mathrm{Hg}$ (II) addition at $\mathrm{pH} 7,8$, and 9 are given in Figure 3. At $\mathrm{pH} 7$, an $\sim 4$-fold fluorescence enhancement occurs following $\mathrm{Hg}(\mathrm{II})$ coordination $\left(\boldsymbol{\Phi}_{\mathrm{Hg}}=0.032\right)$. At pH $8\left(\boldsymbol{\Phi}_{\mathrm{Hg}}=0.064\right)$ and $9\left(\boldsymbol{\Phi}_{\mathrm{Hg}}=\right.$ 0.086 ) the increase in integrated emission is more dramatic, with a $\sim 9$ - and $\sim 11$-fold turn-on, respectively. Interestingly, the nature of the fluorescence enhancement depends on $\mathrm{pH}$.

Significant increases in both the 524 and $624 \mathrm{~nm}$ emission bands contribute to the fluorescence turn-on at $\mathrm{pH} \leq 8$. At higher $\mathrm{pH}, \mathrm{Hg}(\mathrm{II})$ coordination gives rise to only negligible changes in the $524 \mathrm{~nm}$ band, with dramatic increases at $624 \mathrm{~nm}$. This property affords single-excitation dual-emission ratiometric detection of $\mathrm{Hg}(\mathrm{II})$ at $\mathrm{pH}>8$ through comparison of the ratio of the 524 and $624 \mathrm{~nm}(\lambda, 624 / \lambda, 524)$ bands before and after $\mathrm{Hg}(\mathrm{II})$ addition $(\lambda$,ex $=499 \mathrm{~nm})$. For instance, an $\sim 13$-fold ratio change occurs at $\mathrm{pH} 9$. This feature may facilitate quantification in applied work.

The data included in Table 1 indicate that the greater dynamic range in the fluorescence response resulting from $\mathrm{Hg}$ (II) coordination at higher $\mathrm{pH}$ primarily stems from brighter $\mathrm{Hg}$ (II) complexes rather than reduced background emission. This observation contrasts the welldocumented behavior of many proton-sensitive PET-based sensors, which display significantly reduced emission in alkaline solution. ${ }^{59,60}$ Although the photophysical details of this phenomenon warrant further investigation, we propose that the underlying cause of the behavior stems from the protonation state of the seminaphthofluorescein platform and that the seminaphthofluoresein dianion is required for brighter emission from the MS5: $\mathrm{Hg}$ (II) complex. At $\mathrm{pH}$ 7, the seminaphthofluorescein is protonated and monoanionic, hence less emissive. Coordination of MS5 to $\mathrm{Hg}$ (II) does not promote deprotonation of this moiety (vide infra) and, although fluorescence turn-on occurs, emission from the weakly fluorescent monoanonic form of the seminaphthofluorescein results. At $\mathrm{pH}>8$, the seminaphthofluorescein is predominantly in its dianionic and most emissive form. The aniline unit effectively quenches its emission, as evidenced by the $\boldsymbol{\Phi}_{\text {free }}$ values in Table 1, and $\mathrm{Hg}$ (II) coordination restores emission from the dianion.

As observed for MS1-4, the fluorescence response of MS5 to $\mathrm{Hg}$ (II) is sensitive to the presence of chloride ion. Figure 4 shows the fluorescence response of MS5 to $\mathrm{Hg}$ (II) in the presence and absence of chloride ion at $\mathrm{pH} 8$. In $50 \mathrm{mM}$ HEPES, an $\sim 3$-fold fluorescence enhancement occurs upon $\mathrm{Hg}(\mathrm{II})$ coordination, and subsequent introduction of $50 \mathrm{mM}$ chloride ion immediately evokes full turn-on. Substitution of $\mathrm{KCl}$ with $\mathrm{KX}\left(\mathrm{X}=\mathrm{NO}_{3}{ }^{-}, \mathrm{OAc}^{-}, \mathrm{F}^{-}\right)$reveals that this effect is chloride-ion specific, although acetate also gives some emission enhancement. The presence of chloride ion has no effect on the emission of the free sensor. We have encountered such chloride ion dependence for $\mathrm{Hg}$ (II) sensors with a variety of ligand frameworks and have proposed that formation of a $\mathrm{Hg}-\mathrm{Cl}$ bond or strong ion pairing influences the degree of turn-on in these systems. ${ }^{34,35,43}$ Nevertheless, such chloride ion dependence is not completely general. For instance, some xanthenone-substituted Zinpyr sensors that contain di-(2-picolyl)amine ligands, such as ZP3 (Figure 1), give fluorescence enhancement following $\mathrm{Hg}$ (II) coordination and the degree of turn-on is independent of chloride ion in the buffer. ${ }^{58}$ Fluo-5N, a sensor sold by Invitrogen, gives fluorescence turn-on for $\mathrm{Hg}$ (II) and the response is enhanced $\sim 2.5$-fold by substituting chloride with nitrate ion (50 mM PIPES, $100 \mathrm{mM} \mathrm{KX}$, 
$\mathrm{pH} 7) .58$ These observations indicate that buffer composition must be considered when evaluating the response of fluorescent metal ion sensor.

\section{$\mathrm{Hg}$ (II) Binding and Selectivity Studies}

MS5 and MS1 share the same $\mathrm{N}_{2} \mathrm{~S}_{2} \mathrm{O}$ set of chelating donor atoms. A 1:1 binding stoichiometry was previously observed in solution for $\mathrm{Hg}$ (II) complexation to MS1. In this work, we prepared a salicylaldehydebased model complex, $\mathbf{L}$ (Scheme 1), with the aim of elucidating further details about the likely mode of $\mathrm{Hg}$ (II) coordination to these sensors. X-ray quality crystals were obtained by vapor diffusion of $\mathrm{Et}_{2} \mathrm{O}$ into a methanolic solution containing a 1:1 $\mathrm{L} / \mathrm{Hg}$ $\left(\mathrm{ClO}_{4}\right)_{2}$ mixture at room temperature. Tables $\mathrm{S} 1$ and $\mathrm{S} 2$ contain crystallographic data from the refinement as well as selected bond lengths and angles, respectively, for the $\mathbf{L}: \mathrm{Hg}$ (II) complex 6. The unit cell contains the mercury complex, two perchlorate anions, and one molecule of methanol. The $\mathrm{N}(1)$ and $\mathrm{O}(1)$ hydrogen atoms were located from an electron density map. An ORTEP diagram of 6 (Figures 5 \& S5) reveals the $\mathrm{Hg}$ (II) center to be five-coordinate with a distorted trigonal bipyramidal geometry. The protonated phenol oxygen and tertiary amine nitrogen atoms are in the axial positions and the two thioether donors and the protonated aniline nitrogen atom form the equatorial plane. The $\mathrm{Hg}-\mathrm{S}(1)$ and $\mathrm{Hg}-\mathrm{S}(2)$ bond lengths are 2.5076 (8) and 2.4854(8) $\AA$, respectively. These values are within the general $2.47-2.73 \mathrm{~A}$ range for $\mathrm{Hg}$ (II)-S(thioether) bonds and indicate strong Hg-S interactions. ${ }^{61} \mathrm{The} \mathrm{Hg}-\mathrm{O}(1)$ bond length of 2.572(3) $\AA$ suggests a relatively weak interaction. The $\mathrm{Hg}-\mathrm{N}(2)$ distance, 2.436(3) $\AA$, is slightly longer than that of the analogous $\mathrm{Hg}-\mathrm{N}$ bond in $\left[\mathrm{Hg}(\right.$ beppa $\left.)\left(\mathrm{ClO}_{4}\right)\right] \mathrm{ClO}_{4}$, where beppa $=\{N, N$-bis(2-ethylthio)ethyl- $N$-[(6-pivaloylamido-2-pyridyl)methyl $]$ amine, and the bond length of relevance is $2.412(6) \AA .66$ Overall, the structure of $\mathbf{6}$ is similar to that of [(beppa)Hg $\left.\left(\mathrm{ClO}_{4}\right)\right] \mathrm{ClO}_{4}$, although mercury in the latter is described as six-coordinate because of a weak interaction with a perchlorate ion (3.01 $\AA$ ). The beppa ligand itself provides a distorted trigonal bipyramidal geometry, where the tertiary amine and amide oxygen atoms are in the axial positions and two thioether donors and a pyridyl nitrogen atom lie in the equatorial plane. The perchlorate groups of 6 are non-interacting, the closest $\mathrm{Hg}-\mathrm{OClO}_{3}$ interaction being $3.87 \AA$. Although the model compound $\mathbf{6}$ suggests a five-coordinate geometry for the $\mathrm{Hg}$ (II) complex of MS5, in aqueous solution a water molecule (neutral $\mathrm{pH}$ ) or hydroxide ion (basic $\mathrm{pH}$ ) might be weakly associated with, if not bound to, the $\mathrm{Hg}$ (II) center.

The $\mathrm{EC}_{50}$, or concentration of $\mathrm{Hg}(\mathrm{II})$ required to bring about $50 \%$ of the maximum fluorescence enhancement for a $1 \mu \mathrm{M}$ solution of the probe, was determined for MS5 at pH 7 (50 mM PIPES, $100 \mathrm{mM} \mathrm{KCl}$ ). The maximum fluorescence enhancement occurs in the presence of $\sim 10$ equiv of $\mathrm{Hg}$ (II) and the $\mathrm{EC}_{50}$ value is $910 \mathrm{nM}$ (Figure S6). Despite the conserved metal binding unit, this value is higher than that of $\mathrm{MS1}\left(\mathrm{EC}_{50}=410 \mathrm{nM}, \mathrm{pH} 7\right)$. The difference may reflect different protonation states of the fluorescein (MS1) and seminaphthofluorescein (MS5) platforms at $\mathrm{pH} 7$, with phenolate coordination to $\mathrm{Hg}$ (II) for MS1 and phenol coordination to MS5. When a $0.5 \mu \mathrm{M}$ solution of MS5 and $4 \mathrm{~nm}$ slit widths were employed, a lower detection limit of 50 $\mathrm{nM} \mathrm{Hg}$ (II) was obtained at $\mathrm{pH} 7(21 \% \pm 4.5 \%$ fluorescence enhancement, mean \pm SD for 16 trials). 62

Binding of MS5 to $\mathrm{Hg}(\mathrm{II})$ is readily reversible. Addition of TPEN to solutions of MS5 and $\mathrm{Hg}$ (II) caused an immediate fluorescence decrease to within $20 \%$ of the baseline value (Figure 6). This behavior is expected because TPEN has a reported $K_{\mathrm{d}}$ value of $\sim 10^{-25} \mathrm{M}$ for $\mathrm{Hg}$ (II) at $100 \mathrm{mM}$ ionic strength. ${ }^{63}$ Consecutive additions of $\mathrm{Hg}(\mathrm{II})$ and TPEN revealed that this on/ off behavior could be cycled a number of times (Figure 6). Addition of excess KI(aq) also reverses the $\mathrm{Hg}$ (II) binding (data not shown). ${ }^{43,64}$ Such reversibility and regeneration are important for the fabrication of devices to sense mercuric ion.

No crystal structure determination of a TPEN:Hg(II) complex has been published to date and structures of TPEN:Zn(II) complexes have only recently been reported. ${ }^{65}$ Colorless X-ray 
quality block crystals were grown from vapor diffusion of $\mathrm{Et}_{2} \mathrm{O}$ into a methanolic solution of 1:1 TPEN/Hg $\left(\mathrm{ClO}_{4}\right)_{2}$. ORTEP diagrams of 7 are given in Figures 5 and S7; Tables $\mathrm{S} 1$ and 2 contain crystallographic data and select geometric parameters. The $\mathrm{Hg}(\mathrm{II})$ center is sevencoordinate, including one weakly bound perchlorate ion which has a $\mathrm{Hg}-\mathrm{O}(1)$ distance of 2.715 (5) $\AA$. The stereochemistry of the $\mathrm{Hg}(\mathrm{II})$ center is that of a $\mathrm{C}_{2 \mathrm{v}}$ capped trigonal prism. The tertiary amine $\mathrm{Hg}-\mathrm{N}(1)$ and $-\mathrm{N}(2)$ bond lengths are 2.470(5) $\AA$ and 2.434(5) $\AA$ and the bonds between the $\mathrm{Hg}(\mathrm{II})$ center and the pyridyl groups are shorter, ca. $2.35 \AA$, and similar in length to that in $\left[\mathrm{Hg}(\right.$ beppa $\left.\left.) \mathrm{ClO}_{4}\right)\right] \mathrm{ClO}_{4} .66$

Figure 7 depicts the results of metal ion selectivity studies for MS5 at pH 7. The selectivity is analogous to that observed for MS1, 34 with only $\mathrm{Cu}(\mathrm{II})$ interfering with the fluorescence response to $\mathrm{Hg}(\mathrm{II})$. Variations in $\mathrm{pH}$ from $7-9$ have no effect of the observed selectivity, which is also independent of ionic strength and the choice of anion in the buffer.

\section{Simultaneous Detection of $\mathrm{Hg}$ (II) and $\mathrm{Zn}$ (II)}

Multi-analyte sensing is important for simultaneously determining the presence of various components in a mixture. ${ }^{67}$ We therefore determined whether MS5 could perform in combination with an $\mathrm{Hg}$ (II)-insensitive fluoroionophore to detect multiple metal ions in aqueous solution. We choose a fluorescein-based Zn(II) sensor, QZ2 (Figure 1), which has a $\mathrm{Hg}$ (II)-insensitive emission and affords fluorescence enhancement for $\mathrm{Zn}$ (II) in the presence of $\mathrm{Hg}(\mathrm{II}) .{ }^{68}$ Figure 8 depicts the response of a MS5/QZ2 mixture in the presence of $\mathrm{Hg}(\mathrm{II})$, $\mathrm{Zn}(\mathrm{II})$ and both $\mathrm{Hg}(\mathrm{II})$ and $\mathrm{Zn}$ (II) at pH 7. Independent fluorescence changes of MS5 and QZ2 are observed in the presence of only $\mathrm{Hg}$ (II) or $\mathrm{Zn}$ (II), respectively. When a mixture of $\mathrm{Hg}$ (II) and $\mathrm{Zn}(\mathrm{II})$ is added, both sensors respond independently to their respective analytes. The rise centered at $624 \mathrm{~nm}$ indicates the presence of $\mathrm{Hg}$ (II) and that centered at $520 \mathrm{~nm}$ signals $\mathrm{Zn}$ (II). This experiment demonstrates that MS5 can be employed in conjunction with a sensor emitting at shorter wavelengths for multi-analyte detection.

\section{MS5 Performance in Natural Water Samples}

Small molecule fluorescence detectors for $\mathrm{Hg}$ (II) have the potential for use in the field. Such an application presents a unique set of challenges and requires detailed studies of sensor performance in the environmental milieu and method/device design. As a first step towards the former objective, we tested the ability of MS5 to respond to $\mathrm{Hg}$ (II) in natural water. Samples were collected from three sources, including the Charles River (Cambridge, MA), and representative data are given in Figure 9. In each case, MS5 shows $\sim 4.5$-fold or greater fluorescence turn-on in samples spiked with $\mathrm{Hg}(\mathrm{II})$. This result indicates that MS5 can detect $\mathrm{Hg}$ (II) in solutions with significantly more complex composition than laboratory buffer and suggests that its sensitivity to chloride ion will not be a limiting factor for use in environmental monitoring.

\section{Summary}

This work describes the synthesis and characterization of mercury sensor MS5. This sensor was designed to afford low-energy emission, both turn-on and ratiometric fluorescence responses to $\mathrm{Hg}(\mathrm{II})$, and a high degree of $\mathrm{Hg}(\mathrm{II})$ ion selectivity. The solution studies show that $\mathrm{pH}$ is a key factor for generating a ratiometric response to $\mathrm{Hg}$ (II). We propose that this behavior reflects the requirement of the seminaphthofluorescein dianion for significant enhancement of the $624 \mathrm{~nm}$ band, although more detailed physical characterization is needed to address this notion. It became evident during our investigation that the fundamental chemistry of seminaphthofluorescein is relatively unexplored. ${ }^{69}$ Detailed investigations of its protonation and tautomeric equilibria and fluorescence behavior in a number of different solvent systems will be especially helpful in both creating new red-emitting chromophores with enhanced 
brightness at neutral $\mathrm{pH}$ and guiding future sensor design. MS5 gives selective fluorescent enhancement for $\mathrm{Hg}(\mathrm{II})$, binds $\mathrm{Hg}(\mathrm{II})$ rapidly and reversibility, and has a lower detection limit of $50 \mathrm{nM}$ at $\mathrm{pH}$ 7. Preliminary studies in natural water samples indicate that MS5 offers immediate $\mathrm{Hg}$ (II) detection in complex media. This observation points to its potential utility in the field.

\section{Supplementary Material}

Refer to Web version on PubMed Central for supplementary material.

\section{Acknowledgements}

This work was supported by Grant GM65519 from the National Institute of General Medical Sciences. E.M.N. thanks the Whitaker Health Science Fund for a graduate fellowship, Ms. C. W. Nolan for collecting water samples, Drs. D. Song and R. P. Feazell for assistance with the crystal structure determinations and Professor C. Fahrni for a helpful discussion.

\section{References}

1. Renzoni A, Zino F, Franchi E. Environ Res Sec A 1998;77:68-72.

2. Nendza M, Herbst T, Kussatz C, Gies A. Chemosphere 1997;35:1875-1885. [PubMed: 9353909]

3. Bolger PM, Schwetz BA. New Eng J Med 2002;347:1735-1736. [PubMed: 12456847]

4. Harris HH, Pickering IJ, George GN. Science 2003;301:1203. [PubMed: 12947190]

5. Boening DW. Chemosphere 2000;40:1335-1351. [PubMed: 10789973]

6. Clarkson TW, Magos L, Myers GJ. New Eng J Med 2003;349:1731-1737. [PubMed: 14585942]

7. Fan LJ, Zhang Y, Jones WE. Marcomolecules 2005;38:2844-2849.

8. Kim IB, Bunz UWFJ. Am Chem Soc 2006;128:2818-2819.

9. Zhao Y, Zhong ZJ. Am Chem Soc 2006;128:9988-9989.

10. Cheng P, He CJ. Am Chem Soc 2004;126:728-729.

11. Ono A, Togashi H. Angew Chem Int Ed 2004;43:4300-4302.

12. Matsushita M, Meijler MM, Wirsching P, Lerner RA, Janda KD. Org Lett 2005;7:4943-4946. [PubMed: 16235928]

13. Chae MY, Czarnik AWJ. Am Chem Soc 1992;114:9704-9705.

14. Yoon J, Ohler NE, Vance DH, Aumiller WD, Czarnik AW. Tetrahedron Lett 1997;38:3845-3848.

15. Hennrich G, Sonnenschein H, Resch-Genger UJ. Am Chem Soc 1999;121:5073-5074.

16. Prodi L, Bargossi C, Montalti M, Zaccheroni N, Su N, Bradshaw JS, Izatt RM, Savage PBJ. Am Chem Soc 2000;122:6769-6770.

17. Rurack K, Kollmannsberger M, Resch-Genger U, Daub JJ. Am Chem Soc 2000;122:968-969.

18. Hennrich G, Walther W, Resch-Genger U, Sonnenschein H. Inorg Chem 2001;40:641-644. [PubMed: 11225105]

19. Sakamoto H, Ishikawa J, Nakao S, Wada H. Chem Commun 2001:2395-2396.

20. Guo X, Qian X, Jia LJ. Am Chem Soc 2004;126:2272-2273.

21. Métivier R, Leray I, Valeur B. Chem Eur J 2004;10:4480-4490.

22. Dickerson TJ, Reed NN, LaClair JJ, Janda KDJ. Am Chem Soc 2004;126:16582-16586.

23. Zhang G, Zhang D, Yin S, Yang X, Shuai Z, Zhu D. Chem Commun 2005:2161-2163.

24. Liu B, Tian H. Chem Commun 2005:3156-2158.

25. Caballero A, Martínez R, Lioveras V, Ratera I, Vidal-Gancedo J, Wurst K, Tárraga A, Molina P, Veciana JJ. Am Chem Soc 2005;127:15666-15667.

26. Ros-Lis JV, Marcos MD, Mártinez-Máñez R, Rurack K, Soto J. Angew Chem Int Ed 2005;44:44054407.

27. Chen QY, Chen CF. Tetrahedron Lett 2005;46:165-168.

28. Moon SY, Youn NJ, Park SM, Chang SKJ. Org Chem 2005;70:2394-2397. 
29. Yu Y, Lin LR, Yang KB, Zhong X, Huang RB, Zheng LS. Talanta 2006;69:103-106.

30. Kim SH, Kim JS, Park SM, Chang SK. Org Lett 2006;8:371-374. [PubMed: 16435837]

31. Kim SH, Song KC, Ahn S, Kang YS, Chang SK. Tetrahedron Lett 2006;47:497-500.

32. Song KC, Kim JS, Park SM, Chung K-C, Ahn S, Chang SK. Org Lett 2006;8:3413-3416. [PubMed: 16869623]

33. Czarnik AW. Ace Chem Res 1994;27:302-308.

34. Nolan EM, Lippard SJJ. Am Chem Soc 2003;125:14270-14271.

35. Nolan EM, Lippard SJJ. Mater Chem 2005;27-28:2778-2783.

36. Mello JV, Finney NSJ. Am Chem Soc 2005;127:10124-10125.

37. Yang YK, Yook KJ, Tae JJ. Am Chem Soc 2005;127:16760-16761.

38. Wang J, Qian X. Chem Commun 2006:109-111.

39. Yoon S, Albers AE, Wong AP, Chang CJJ. Am Chem Soc 2006;127:16030-16031.

40. Zheng H, Qian ZH, Xu L, Yuan FF, Lan LD, Xu JG. Org Lett 2006;8:859-861. [PubMed: 16494459]

41. Wang J, Qian X, Cui JJ. Org Chem 2006;71:4308-4311.

42. Wang J, Xuhong Q. Org Lett 2006;8:3721-3724. [PubMed: 16898801]

43. Nolan EM, Racine ME, Lippard SJ. Inorg Chem 2006;45:2742-2749. [PubMed: 16529499]

44. Ko SK, Yang WK, Tae J, Shin IJ. Am Chem Soc 2006;128:14150-14155.

45. Descalzo AB, Martinez-Manez R, Radeglia R, Rurack K, Soto JJ. Am Chem Soc 2003;125:34183419.

46. Rurack K, Resch-Genger U, Bricks JL, Spieles M. Chem Commun 2000:2103-2104.

47. Zhu XJ, Fu ST, Wong WK, Guo JP, Yong WY. Angew Chem Int Ed 2006;45:3150-3154.

48. Chang CJ, Jaworski J, Nolan EM, Sheng M, Lippard SJ. Proc Natl Acad Sci USA 2004;101:1129_ 1134. [PubMed: 14734801]

49. SMART: Software for the CCD Detector System, version 5.626. Bruker AXS; Madison, WI: 2000.

50. Kuzelka J, Mukhopadhyay S, Spingler B, Lippard SJ. Inorg Chem 2004;43:1751-1761. [PubMed: 14989668]

51. Sheldrick, GM. SADABS: Area-Detector Absorption Correction. University of Gottingen; Gottingen, Germany: 2001.

52. SAINTPLUS: Software for the CCD Detector System, version 5.01. Bruker AXS; Madison, WI: 1998.

53. SHELXTL: Program Library for Structure Solution and Molecular Graphics, version 6.1. Bruker AXS; Madison, WI: 2001.

54. Spek, A. PLATON, A Multipurpose Crystallographic Tool. Utrecht University; Utrecht, The Netherlands: 2000.

55. Brannon JH, Madge DJ. Phys Chem 1978;82:705-709.

56. Whitaker JE, Haugland RP, Prendergast FG. Anal Biochem 1991;194:330-344. [PubMed: 1862936]

57. Sjöback R, Nygren J, Kubista M. Spectrochimica Acta Part A 1995;51:L7-L21.

58. Nolan EM, Lippard SJ. Unpublished results

59. de Silva AP, Gunaratne HQN, Gunnlaugsson T, Huxley AJM, McCoy CP, Rademacher JT, Rice TE. Chem Rev 1997;97:1515-1566. [PubMed: 11851458]

60. Callan JF, de Silva AP, Magri DC. Tetrahedron 2005;61:8551-8588.

61. Wright JG, Natan FM, MacDonnell FM, Ralston DM, O’Halloran TV. Prog Inorg Chem 1990;38:323-412.

62. A $500 \mathrm{nM}$ concentration of MS5 was employed because we were unable to obtain reliable data with lower concentrations and $4 \mathrm{~nm}$ slit widths.

63. Anderegg, vG; Hubmann, E.; Fodder, NG.; Wenk, F. Helv Chim Acta 1977;60:123-140.

64. Coronado E, Gálan-Mascarós JR, Martí-Gastaldo C, Palomares E, Durrant JR, Vilar R, Gratzel M, Nazeeruddin MKJ. Am Chem Soc 2005;127:12351-12356.

65. Mikata Y, Wakamatsu M, Yano S. Dalton Trans 2005:545-550. [PubMed: 15672199]

66. Makowska-Grzyska MM, Doyle K, Allred RA, Arif AM, Bebout DC, Berreau LM. Eur J Inorg Chem 2005:822-827. 
67. Walt DR. Current Opin Chem Biol 2002;6:689-695.

68. Nolan EM, Jaworski J, Okamoto KI, Hayashi Y, Sheng M, Lippard SJJ. Am Chem Soc 2005; 127:16812-16823.

69. A SciFinder search yielded only 39 hits and only 116 for "seminaphthofluorescein" and only 115 for "SNAFL" compared to over 60,000 hits generated by "fluorescein" in November of 2006. 
<smiles>CCSCCN(CCSCC)Cc1ccccc1NCc1c(O)ccc2c(-c3ccccc3C(=O)O)c3cc(Cl)c(=O)cc-3oc12</smiles>

MS1

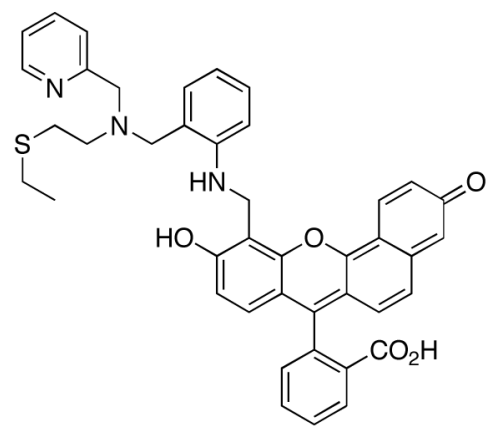

MS4

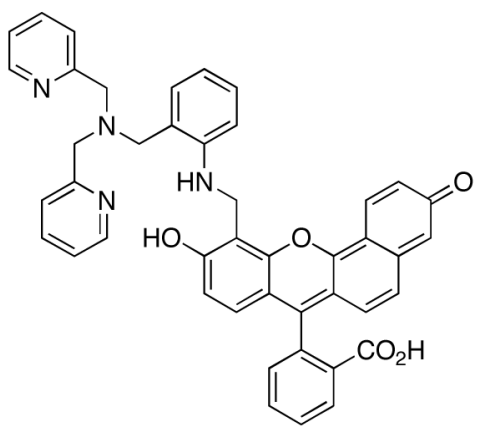

ZNP1

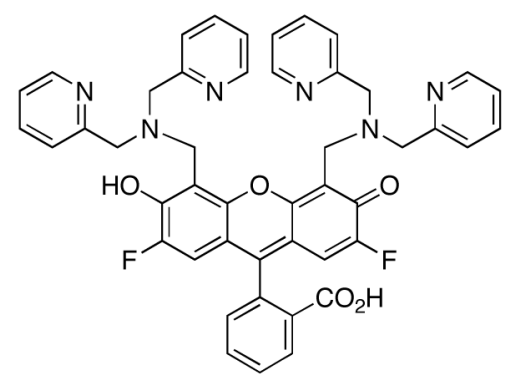

ZP3

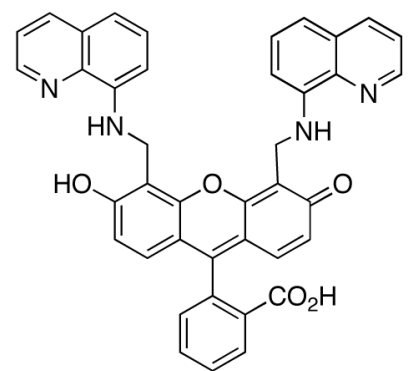

QZ2

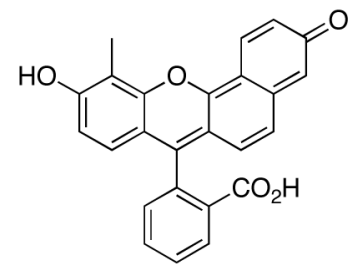

3

Figure 1.

Structures of metal ion sensors and seminaphthofluorescein $\mathbf{3}$ 

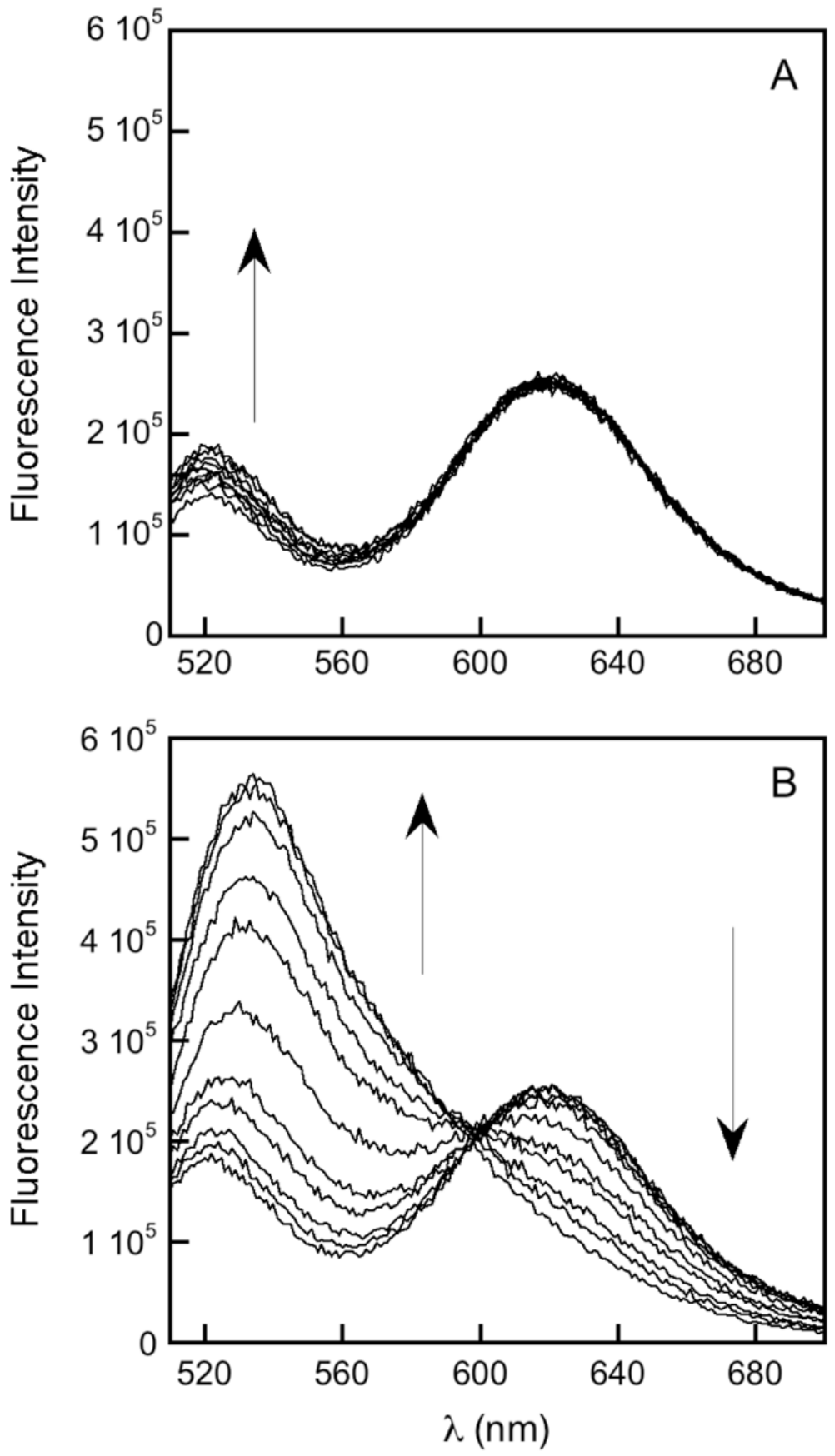

Figure 2.

Effect of $\mathrm{pH}$ on the emission of $5 \mu \mathrm{M}$ MS5 $\left(100 \mathrm{mM} \mathrm{KCl}, \lambda\right.$,ex $\left.=499 \mathrm{~nm}, \mathrm{~T}=25^{\circ} \mathrm{C}\right)$. A. The $\mathrm{pH}$ was decreased from $\sim 12$ to $\sim 9$ in increments of $\sim 0.25$. B. The $\mathrm{pH}$ was decreased from $\sim 9$ to $\sim 6$ in increments of $\sim 0.25$. See Figure $\mathrm{S} 4$ for data taken at $\mathrm{pH}<6$. 

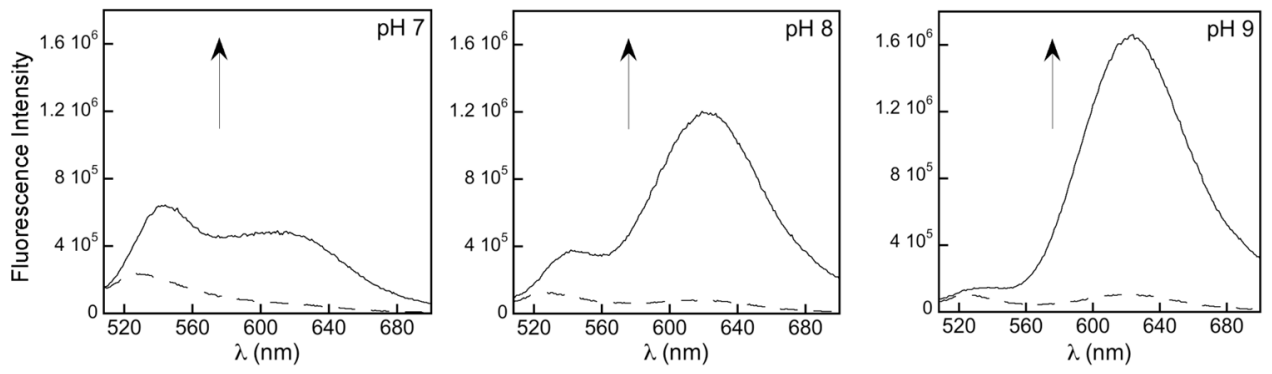

Figure 3.

Fluorescence response of MS5 to $\mathrm{Hg}(\mathrm{II})$ as a function of $\mathrm{pH}$. The dotted lines represent the emission from $5 \mu \mathrm{M}$ MS5 at $\mathrm{pH} 7$ (50 mM PIPES, $100 \mathrm{mM} \mathrm{KCl}), \mathrm{pH} 8$ (50 mM HEPES, 100 $\mathrm{mM} \mathrm{KCl})$ and $9(50 \mathrm{mM} \mathrm{CHES,} 100 \mathrm{mM} \mathrm{KCl})$. The solid lines represent the emission change that occurs immediately upon addition of 20 equiv of $\mathrm{HgCl}_{2}$. The samples were excited at 499 $\mathrm{nm}$ and $\mathrm{T}=25^{\circ} \mathrm{C}$. 

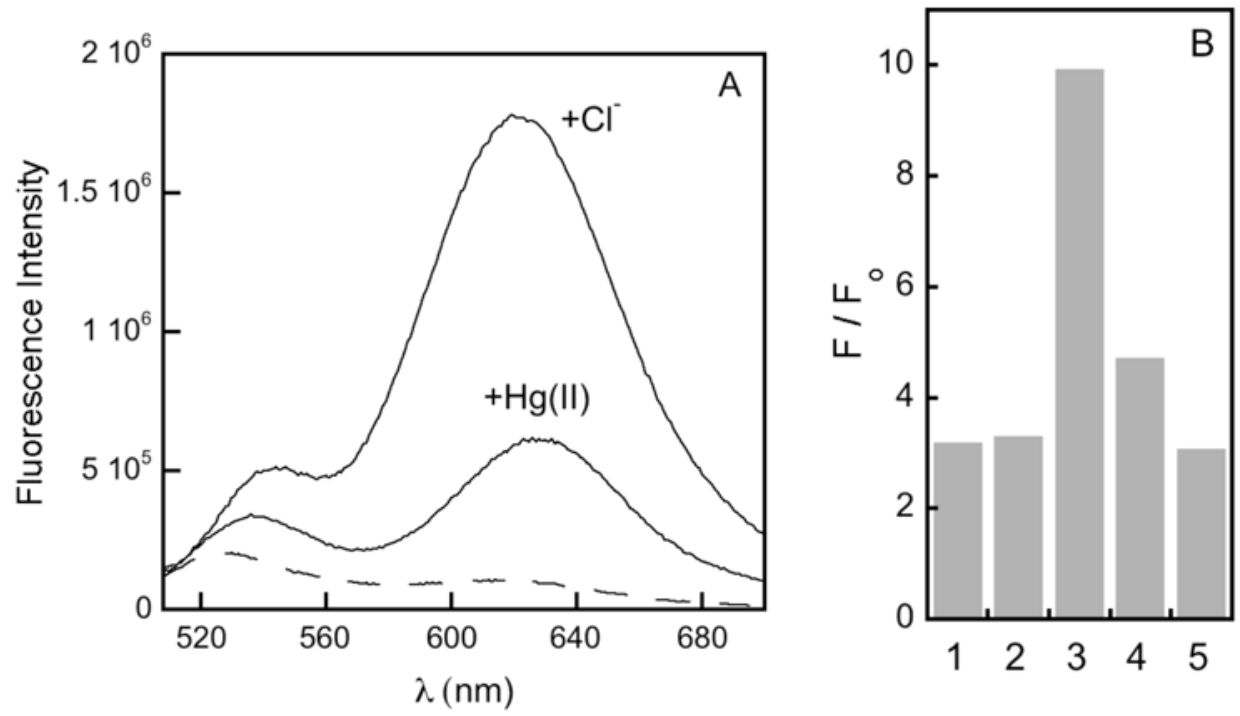

Figure 4.

Effect of anions on the emission of the MS5:Hg(II) complex. A. The dashed line represents the emission from $5 \mu \mathrm{M}$ MS5 in the absence of chloride ion (50 mM HEPES, pH 8). Addition of 20 equiv of $\mathrm{Hg}$ (II) results in $~ 3$-fold fluorescence enhancement. Full emission is restored immediately after addition of aqueous $\mathrm{KCl}$ (final concentration $=100 \mathrm{mM}$ ). B. The effect of various anions in the buffer (50 mM HEPES, $100 \mathrm{mM} \mathrm{KX}, \mathrm{pH}$ 8): 1, no potassium salt; 2 , $\mathrm{KNO}_{3} ; \mathbf{3}, \mathrm{KCl} ; \mathbf{4}, \mathrm{KOAc} ; \mathbf{5}, \mathrm{KF}$. $\mathrm{F}$ is the fluorescence observed after $\mathrm{Hg}(\mathrm{II})$ addition and $\mathrm{F}_{\mathrm{O}}$ is the emission from free MS5. The samples were excited at $499 \mathrm{~nm}$ and $\mathrm{T}=25^{\circ} \mathrm{C}$. 


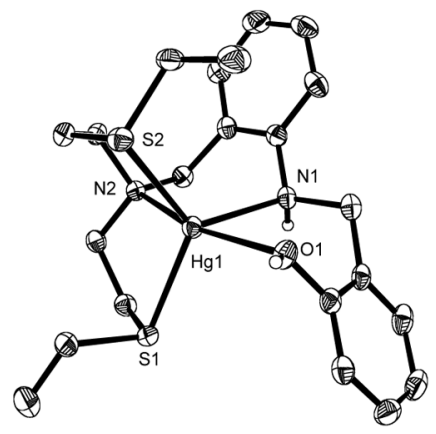

6

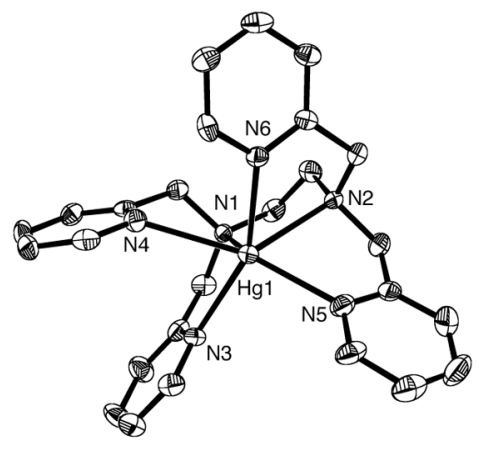

7

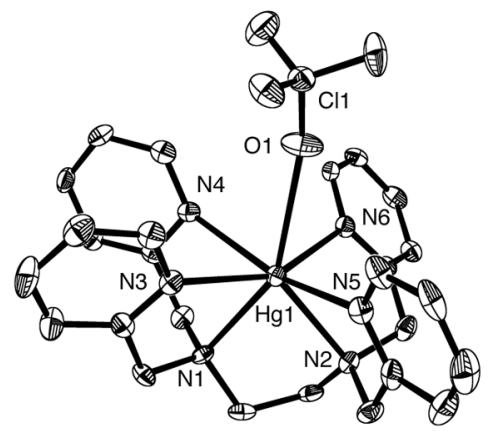

7

Figure 5.

ORTEP diagrams of the $\mathrm{Hg}(\mathrm{II})$ complexes 6 and 7. The ORTEP diagrams of 6 and 7 depict the $40 \%$ probability thermal ellipsoids for all non-hydrogen atoms. The left and middle ORTEP diagrams omit the perchlorate counterions. The right-most ORTEP diagram of 7 illustrates the orientation of the weakly associated perchlorate anion. The $\mathrm{Hg}(1)-\mathrm{O}(1)$ distance is 2.715(5) A. 


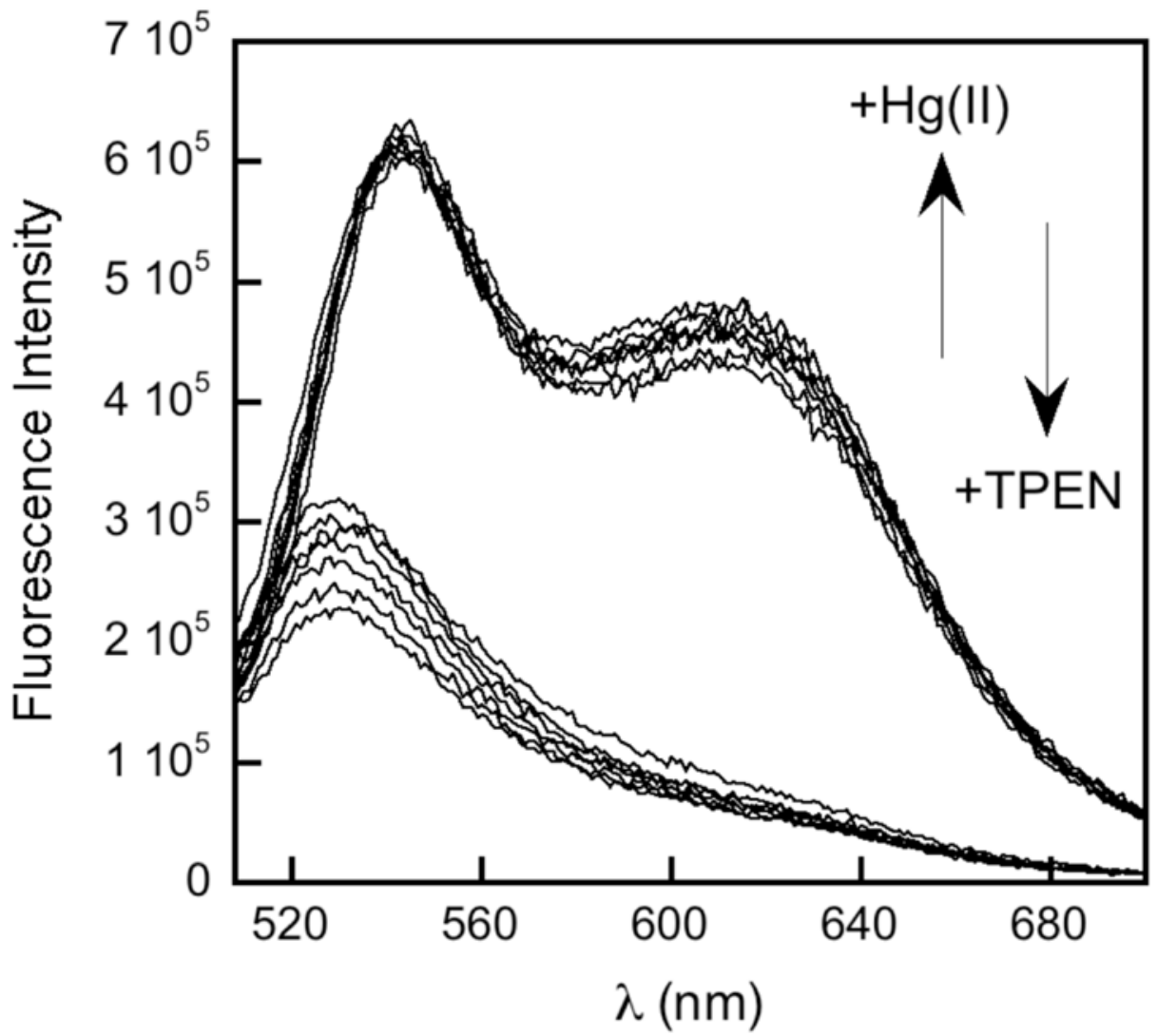

Figure 6.

Reversibility of $\mathrm{Hg}(\mathrm{II})$ coordination to $5 \mu \mathrm{M}$ MS5 by TPEN addition (50 mM PIPES, $100 \mathrm{mM}$ $\mathrm{KCl}, \mathrm{pH} 7$ ). The top set of solid lines represent the fluorescence enhancement that occurs immediately after addition of 10 equiv of $\mathrm{Hg}$ (II). The bottom set of solid lines represents the emission from free MS5 and the emission decreases that occur immediately after addition of 10 equiv of TPEN to a solution containing the MS5:Hg(II) complex. Six cycles of on/off by $\mathrm{Hg}$ (II)/TPEN addition are depicted in this plot and the slight fluorescence rise observed in the bottom spectra ca. $530 \mathrm{~nm}$ results from TPEN emission (control data not shown). The samples were excited at $499 \mathrm{~nm}$ and $\mathrm{T}=25^{\circ} \mathrm{C}$. 


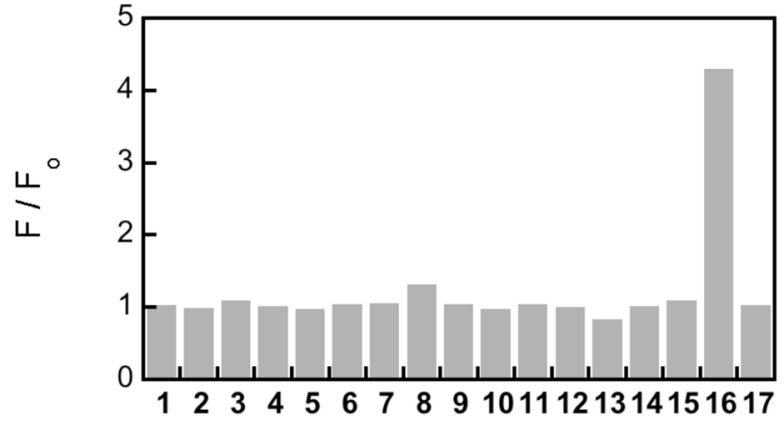

\begin{tabular}{|c|c|}
\hline 1, Li(I) & $10, \mathrm{Fe}(\mathrm{II})$ \\
\hline 2, $\mathrm{Na}(\mathrm{l})$ & $11, \mathrm{Co}(\mathrm{II})$ \\
\hline 3, $\mathrm{Rb}(\mathrm{I})$ & 12, $\mathrm{Ni}(\mathrm{II})$ \\
\hline 4, Mg(II) & 13, $\mathrm{Cu}(\mathrm{II})$ \\
\hline 5, Ca(II) & $14, \mathrm{Zn}(\mathrm{II})$ \\
\hline 6, $\operatorname{Sr}(I I)$ & $15, \mathrm{Cd}(\mathrm{II})$ \\
\hline 7, $\mathrm{Ba}(\mathrm{II})$ & $16, \mathrm{Hg}(\mathrm{II})$ \\
\hline 8, Mn(II) & 17, $\mathrm{Pb}(\mathrm{I}$ \\
\hline , $\mathrm{Cr}(\mathrm{III}$ & \\
\hline
\end{tabular}

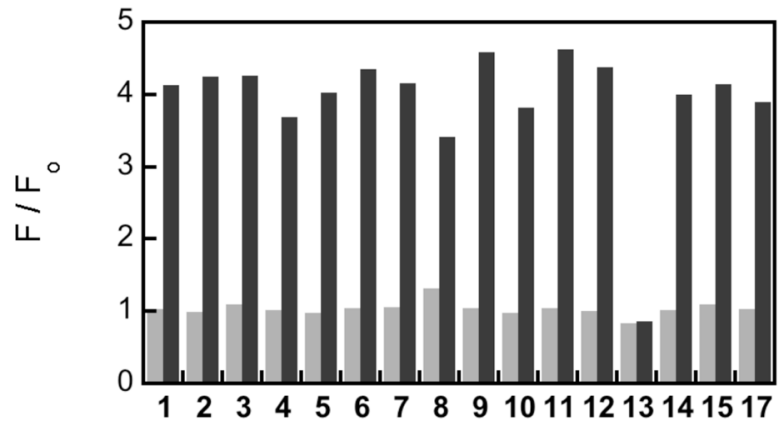

9, $\mathrm{Cr}(\mathrm{III})$

Figure 7.

Selectivity of MS5 for $\mathrm{Hg}(\mathrm{II})$ over other cations at pH 7 (50 mM PIPES, $100 \mathrm{mM} \mathrm{KCl).} \mathrm{Top}$ plot: Fluorescence response of $5 \mu \mathrm{M}$ MS5 following addition of 20 equiv of the cation of interest: $1, \mathrm{LiCl} ; 2, \mathrm{NaCl} ; 3, \mathrm{RbCl} ; 4, \mathrm{MgCl}_{2} ; 5, \mathrm{CaCl}_{2} ; 6, \mathrm{SrCl}_{2} ; 7, \mathrm{BaCl}_{2} ; 8, \mathrm{MnCl}_{2} ; 9, \mathrm{Cr}$ $\left(\mathrm{CH}_{3} \mathrm{CO}_{2}\right)_{3} ; 10, \mathrm{Fe}\left(\mathrm{NH}_{4}\right)_{2}\left(\mathrm{SO}_{4}\right)_{2} ; 11, \mathrm{CoCl}_{2} ; 12, \mathrm{NiCl}_{2} ; 13, \mathrm{Cu}\left(\mathrm{SO}_{4}\right)_{2} ; 14, \mathrm{ZnCl}_{2} ; 15$, $\mathrm{CdCl}_{2} ; 16, \mathrm{HgCl}_{2} ; 17, \mathrm{~Pb}\left(\mathrm{NO}_{3}\right)_{2}$. Bottom plot: The light grey bars correspond to the bars in the top plot. The black bars indicate the fluorescence change that occurs immediately following addition of 20 equiv of $\mathrm{Hg}$ (II) to the solutions containing MS5 and the cation of interest. All data $(\mathrm{F})$ were normalized with respsect to emission of the free sensor $\left(\mathrm{F}_{0}\right)$. The samples were excited at $499 \mathrm{~nm}$ and the emission integrated from $505-700 \mathrm{~nm}$. T $=25^{\circ} \mathrm{C}$. MS5 is also selective for $\mathrm{Hg}$ (II) in the presence of millimolar concentrations of the alkali and alkaline earth metals (data not shown). 


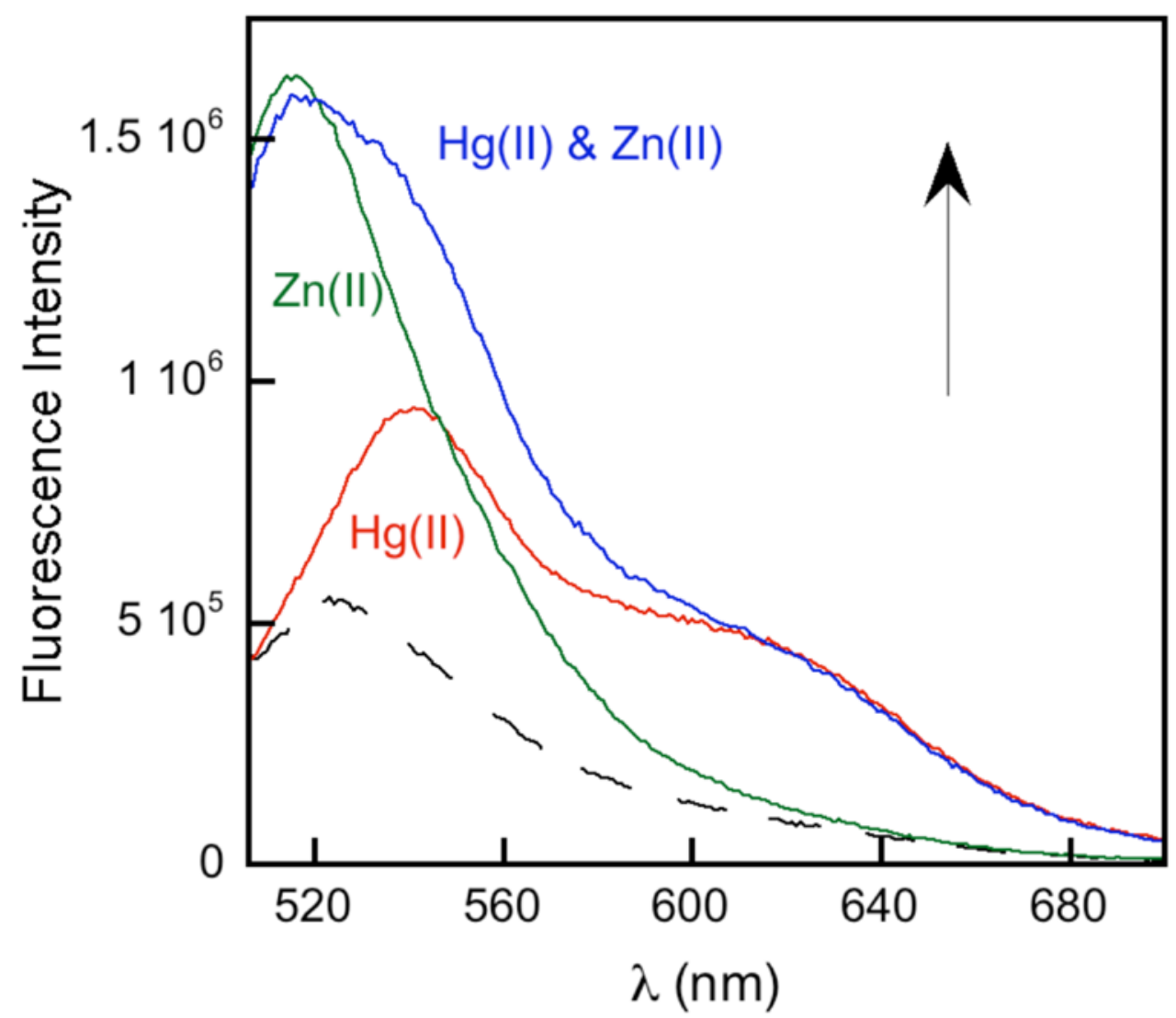

Figure 8.

Fluorescence response to $\mathrm{Hg}$ (II) and $\mathrm{Zn}$ (II) from a mixture of $5 \mu \mathrm{M}$ MS5 and $100 \mathrm{nM}$ QZ2 at pH 7 (50 mM PIPES, $100 \mathrm{mM} \mathrm{KCl).} \mathrm{The} \mathrm{black} \mathrm{dashed} \mathrm{line} \mathrm{represents} \mathrm{emission} \mathrm{from} \mathrm{the} \mathrm{MS5/}$ QZ2 mixture. The red line is the emission from the mixture immediately after addition of only $50 \mu \mathrm{M} \mathrm{Hg}$ (II). The green line is the emission from the mixture immediately after addition of only $50 \mu \mathrm{M} \mathrm{Zn(II).} \mathrm{The} \mathrm{blue} \mathrm{line} \mathrm{is} \mathrm{the} \mathrm{response} \mathrm{in} \mathrm{the} \mathrm{presence} \mathrm{of} \mathrm{both} 50 \mu \mathrm{M} \mathrm{Hg}$ (II) and $\mathrm{Zn}$ (II). The samples were excited at $499 \mathrm{~nm}$ and $\mathrm{T}=25^{\circ} \mathrm{C}$. 

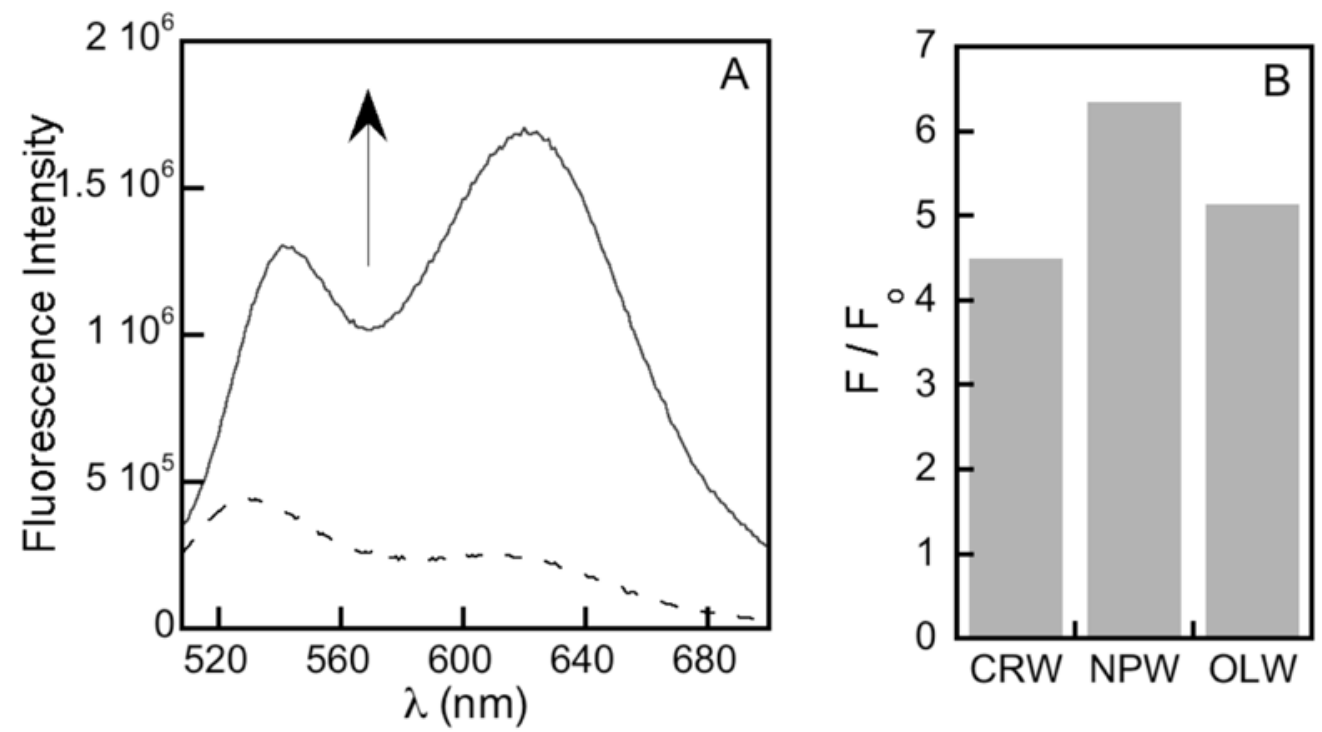

Figure 9.

Response of $5 \mu \mathrm{M}$ MS5 to 10 equiv of $\mathrm{Hg}$ (II) added to natural water samples. A. Emission spectra for MS5 in Charles River water before (dashed line) and after (solid line) addition of 10 equiv of $\mathrm{Hg}$ (II). B. Fluorescence response of MS5 to $\mathrm{Hg}$ (II) in Charles River water (CRW), Newburyport water (NPW) and Onondaga Lake water (OLW). The response (F) is normalized to the emission of the free sensor $\left(\mathrm{F}_{0}\right)$. The samples were excited at $499 \mathrm{~nm}$ and $\mathrm{T}=25^{\circ} \mathrm{C}$. 


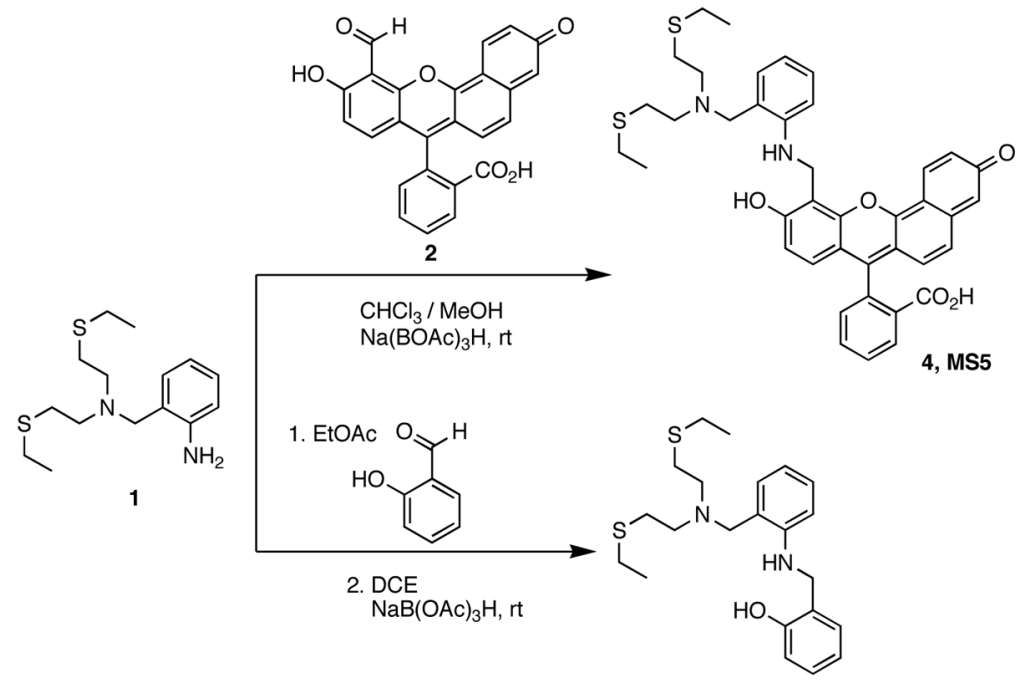

$5, \mathrm{~L}$

Scheme 1.

Synthesis of MS5 and its salicylaldehyde-based analog $\mathbf{L}$. 
Table 1

Spectroscopic Properties of MS5 ${ }^{a}$

\begin{tabular}{|c|c|c|c|c|}
\hline \multirow[t]{2}{*}{ PH } & \multicolumn{2}{|c|}{ Absorption $\lambda(\mathrm{nm}) ; \varepsilon \times 10^{3}\left(\mathrm{M}^{-1} \mathrm{~cm}^{-1}\right)$} & \multicolumn{2}{|c|}{ Emission $\lambda(\mathrm{nm}) ; \Phi^{b}$} \\
\hline & Unbound & $\mathbf{H g}(\mathrm{II})$ & Unbound & $\mathbf{H g}(\mathbf{I I})$ \\
\hline 7 & $5004.5 ; 528,4.5$ & $492,7.0 ; 533,7.8$ & 536,$611 ; 0.018$ & 524,$612 ; 0.032$ \\
\hline 8 & $531,12.2$ & $541,16.0$ & 532,$612 ; 0.009$ & 546,$624 ; 0.064$ \\
\hline 9 & $552,24.2$ & $547,27.2$ & 522,$620 ; 0.010$ & 534,$624 ; 0.086$ \\
\hline
\end{tabular}




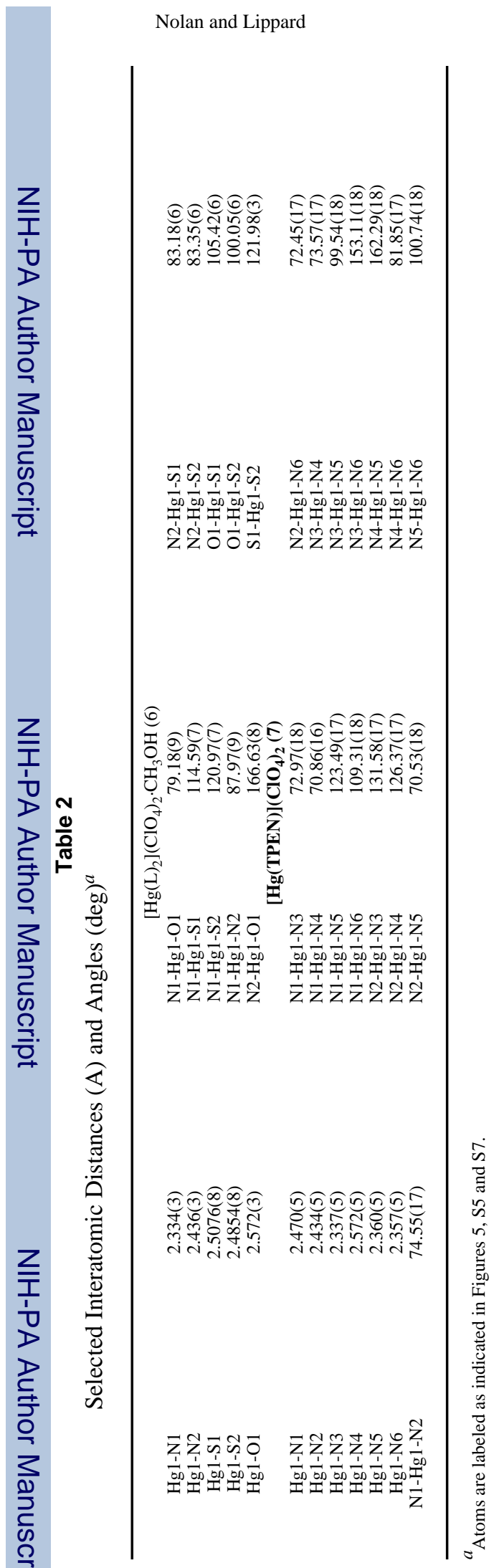

Page 23

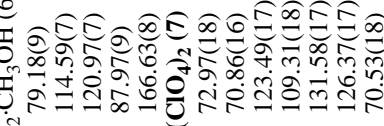

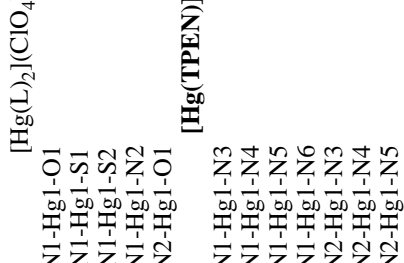

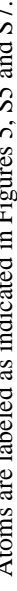

$J$ Am Chem Soc. Author manuscript; available in PMC 2008 August 11. 